WAR AND PEACE: ARTHUR C. PIGOU AS A PUBLIC INTELLECTUAL DURING

WORLD WAR I

BY ROGÉRIO ARTHMAR AND MICHAEL MCLURE *

\begin{abstract}
This study reflects on Arthur Cecil Pigou's role in public debate during the initial phase of the First World War over whether Britain should negotiate a peace treaty with Germany. Its main goal is to provide evidence that the Cambridge Professor framed his approach to this highly controversial issue from theoretical propositions on trade, industrial peace and welfare which he had developed in previous works. After reviewing his contributions on these subjects, Pigou's letter to The Nation, in early 1915, suggesting an open move by the Allies towards an honourable peace with Germany, is presented along with his more elaborate thoughts on this same theme put down in a private manuscript. The negative reactions to Pigou's letter are then scrutinized, particularly the fierce editorial published by The Morning Post. A subsequent version of Pigou's plea for peace, delivered in his London speech late in 1915, is detailed listing the essential conditions for a successful conclusion of the conflict. To come full circle, the paper recapitulates Pigou's post-war considerations on diplomacy, free trade and colonialism. The concluding remarks bring together the theoretical and applied branches of Pigou's thoughts on war and peace.

* Economia, Universidade Federal do Espírito Santo. Contact: rarthmar@gmail.com

** University of West Australia. Contact: michael.mclure@uwa.edu.au
\end{abstract}

This "preprint" is the peer-reviewed and accepted typescript of an article that is forthcoming in revised form, after minor editorial changes, in the Journal of the History of Economic Thought (ISSN: 1053-8372), issue TBA. Copyright to the journal's articles is held by the History of Economics Society (HES), whose exclusive licensee and publisher for the journal is Cambridge University Press. (https://www.cambridge.org/core/journals/journal-of-the-history-of-economicthought) This preprint may be used only for private research and study and is not to be distributed further.

The preprint may be cited as follows:

Arthmar, Rogério and Michael McLure. "War and Peace: Arthur C. Pigou as a Public Intellectual during World War I". Journal of the History of Economic Thought (forthcoming). Preprint at SocArXiv, osf.io/preprints/socarxiv 


\section{War and Peace: Arthur C. Pigou as a Public Intellectual during World War I}

\section{Introduction}

Despite the considerable literature on Arthur Cecil Pigou's contribution to war finance and arrangements for peacetime monetary reconstruction (Arthmar and McLure 2017b; Kumekawa 2017, pp. 8-82; Aslanbeigui and Oakes 2016, 2015, pp. 42-95; Collard 1981), scholars have only given brief notice to his proposal, put forward in the press and on public speeches in 1915, for Britain to seek an honourable peace with Germany (see, however, Wallace 1988, pp. 144-147). Pigou's stance on this extremely delicate matter reverberated nationwide in several newspapers. The 'Cambridge Professor' has been portrayed as typically reluctant to offer advice on public issues based solely on abstract principles (Aslanbeigui and Oakes 2015: 97-135). ${ }^{1}$ But contrary to that perception, during Wold War I he engaged in debate through the media over the terms of peace, and he did so in a manner that not only revealed his personal humanistic side, but also the use of quite a few analytical propositions from his books The Riddle of the Tariff (1904), Principles and Methods of Industrial Peace (1905) and Wealth and Welfare (1912) to the field of war diplomacy. The controversy Pigou sparked by advocating for a negotiated peace was intense and bitter, but ultimately with no impact on the way Britain prosecuted the war. The episode, however, had a significant influence on his scholarly development, culminating in the attempt to unify the different branches of his previous works in The Economics of Welfare (1920). Furthermore, the following year, he published The Political Economy of War (1921), a book designed to provide a deeper

\footnotetext{
${ }^{1}$ In a 1930 lecture on the role of economists in society, though, Pigou recalled his cherished distinction between science as a source of light and fruit, remarking that addressing concrete matters could hugely benefit from quite abstract intellectual speculations: "The experience of the natural sciences affords abundant proof that is not always the study of immediate practical problems that helps practice most. Remoter, more fundamental, so to speak more theoretical, investigations sometimes in the end yield the largest harvests" (Pigou 1935: 6).
} 
look into the causes of the conflict and manifesting, in large measure, the insights gained from his participation in the debate over war diplomacy.

Our purpose in what follows is to shed light on the conditions surrounding this significant event in Pigou's life as a public intellectual, stressing his perseverance, under the most adverse conditions, in applying his theoretical propositions on trade, industrial peace and welfare to justify an appeasement with the enemy. Keeping this objective in sight, the present paper is structured in the following way. The second section introduces some preliminary attributes of Pigou's theoretical works that he used as a springboard for his bold jump into the public arena on the vexed issue of war time diplomacy. In the third section, the state of the peace movement and the general case for war within British society are outlined, while Pigou's reasons for a moderate peace, as expressed in his controversial letter to The Nation early in February 1915 and in a contemporary unpublished manuscript, are put forward. The fourth section reviews the public controversy that his proposal generated, especially in the pages of The Morning Post. Pigou's defence of a motion for peace at the traditional Cambridge Union is also considered, as is his lecture at the Devonshire House later in the same year. The fifth section reflects on Pigou's ideas on industrial peace and the causes of war in the early 1920s. This inquiry concludes with some final observations on how Pigou's case for a swift end to hostilities during World War I was influenced by his theoretical conceptions and his understanding of the relationship between welfare economics and international diplomacy.

\section{Pigou's early writings on trade, industrial peace and welfare}

By the time Pigou came to debate war diplomacy in 1915, he had already developed a framework for investigating the consequences of protectionism, industrial peace and welfare that would largely inform his judgement on Britain's best path for returning to peace. His short book The Riddle of the Tariff, which came out in 1904, attributed the then ongoing revival of protectionist discourse towards the formation of a customsunion with the dominions to ill-intentioned journalists and pamphleteers. ${ }^{2}$ Pigou's

\footnotetext{
${ }^{2}$ By 1903, Joseph Chamberlain, then Secretary of State for the Colonies, and William Hewin, a conservative professor of the London School of Economics, started a campaign in favour of reimposing
} 
overall attitude in favour of free trade was based, first, on the domestic misallocation of resources induced by duties on foreign commodities and, second, on the fear that protection would replace economic with political competition, fostering the growth of sinister interests among manufacturers and traders striving to obtaining tariff favours from politicians.

With respect to imperial preference, Pigou counsels that such measure would bring forth immaterial benefits to Britain and the dominions, whereas the losses imposed on countries outside the bloc could not fail to arise the sharp opposition of foreign powers with which Britain kept large commercial ties. To avoid the deepening of tensions and unnecessary tariff wars, economic diplomacy should be accompanied by geopolitical concessions. Thus, commenting on the 1897 law by Canada offering tariff privileges to imports from the mother country and increasing the duties on Belgian and German goods, Pigou concedes that Germany was correct in replying to such move by counter-increasing the duties on its Canadian imports. ${ }^{3} \mathrm{He}$ also recommends the use by Britain of less conventional measures in like situations to appease foreign powers, a proposal that would be subsequently used against him by the media (for the controversial passage, see Pigou 1904, p. 58).

In his Principles and Methods of Industrial Peace (1905), Pigou subjects the machinery of arbitration between employers and employees to economic analysis to demonstrate that social conciliation could be a suitable mechanism for avoiding costly and socially disruptive struggles. From a historical standpoint, Pigou explains that, at first, employers saw the workers' organizations as dangerous and tried every conceivable way to prohibit or simply dismantle them. In response, labour unions promoted long and violent strikes to impress industrialists with the power of organised labour. In such circumstances, both parties tended to carry any conflict beyond the

long supressed tariffs on foreign goods as the best policy to increase Britain prosperity and fiscal revenues (Aslanbeigui and Oakes 2017, pp. 42-57; Coats 1968).

${ }^{3}$ In 1897 tariff preference for British goods was enacted by the Canadian Parliament and came into law shortly after that. At the time, however, Britain, had already concluded commercial treaties with Belgium and Germany. This led the Zollverein (German Customs Union) to contend that any concessions extended to the United Kingdom by its colonies must also be granted to Belgium and Germany. Later that year, the Canadian law was ruled unconstitutional by the Imperial Crown (Shields 1965). 
initial point of contention. Once negotiations between the opposing sides are established, however, trust begins to built-up and a clear understanding of disagreements emerges, as do the potential avenues for overcoming differences. The feelings associated with goodwill and achievement reinforce each other and the ensuing beneficial effects are compounded until the machinery of negotiations becomes the usual practice, often through a supporting bureaucratic system. ${ }^{4}$ Even if a temporary relapse into conflict takes place, says Pigou, the losses consequent on this course of action would be soon made evident to everyone; and the advantages obtained by the method of conciliation, as well as the magnitude of the evils it avoids, would again be appreciated. A cumulative growth in reciprocal understanding then arises between the contending sides. As Pigou wrote:

$$
\begin{aligned}
& \text { Sympathy tends to the search for knowledge; knowledge furthers sympathy; both of } \\
& \text { them check strikes, and the absence of strikes promotes both of them. Improved } \\
& \text { organisation makes for peaceful settlements; these, if arranged on sound principles, give } \\
& \text { satisfaction and encourage a further development of the experiment. There is, in fact, a } \\
& \text { continuous interplay of action and reaction, advance in one direction being both cause } \\
& \text { and consequence of advance in others (Pigou 1905, p. 31). }
\end{aligned}
$$

In view of this, the value of compromise to society-at-large is at its greatest when ignorance or passion stands in the way of rational action, such as when employers and employees act together to curtail production and increase prices. To prevent this kind of situation, Pigou argued that a refusal of arbitrage when negotiations stall should be met by a substantial penalty being imposed upon the obstinate party. Without this kind of procedure, conflicts would become the norm in industrial disputes, making peaceful talks attractive just when sheer obstinacy could no longer give any result. Pigou's two most important conditions for the prevalence of harmony in the industrial world were, first, to take into account everyone who is directly or indirectly affected by the settlement; and second, to acknowledge that an ideal outcome from the perspective of one party could prove too costly or deeply injurious to other parties. Negotiators or arbitrators, continued Pigou, must therefore be mindful of the feasibility of their

\footnotetext{
${ }^{4}$ Recently, Karen L. Knight has examined the influence of German philosophers Rudolf Hermann Lotze and Friedrich Wilhelm Nietzsche on Pigou's ethical and economic doctrines, especially via his emphasis on the people's states of mind (Knight 2018, pp. 149-195). This idealistic connection helps explain the importance Pigou attributed to understanding and goodwill in the realms of economic life and international relations.
} 
proposals by considering the specificity of each context, recognising that what they conceive as the best outcome is, all too often, not a practical one (Pigou 1905, pp. 52$56)$.

In his most famous work, Wealth and Welfare, Pigou introduced two fundamental concepts destined to play a major part in most of his future writings on practical issues. One, the idea, originally devised by Henry Sidgwick, that economic actions could bring about unaccounted effects to third parties and which are divergent from the corresponding private returns. Additionally, as such approach widened the scope of economics, it gave prominence to the welfare of society, a concern that had already loomed large to Marshall, particularly on the condition of the poor working people (Arthmar and McLure 2017a). A clear instance of how these theoretical principles were to be articulated by Pigou when examining very specific problems -a central concern of this paper-, may be found in the speech he delivered in the 1914 Warburton Lecture at Manchester University, when talking about the housing problem in Britain. Besides the visible run-off state of houses and their overcrowding in poor areas, Pigou pointed out as even more critical than these aspects the always neglected harmful impact of congested towns and lack of public spaces over the children's health and character development (Pigou 1965, pp. 112-125; for similar examples, see the remainder of Essays on Applied Economics).

The relevance of Pigou's analytical works (Pigou 1904, 1905 and 1912) dealing with protectionism, industrial peace and welfare respectively, to his role as a public intellectual during Wold War I and in its aftermath are therefore three-fold. First, he understood tariff protection as the effect of a moral debasement of the domestic political system, but with far reaching consequences on the international level by intensifying political rivalry among nations and undermining thus the efforts for peace preservation. Second, he regarded negotiations between contending parties as an essential step to promote harmony and stability in the economic domain, with his subsequent accounts of the benefits of diplomatic talks between governments in times of war largely reflecting his thoughts on industrial peace. Finally, just as Pigou's privileged the proper assessment of hidden social costs and the position of the poorer classes in his treatment of welfare, he extended this same concern for their suffering during the war, irrespective of whether the country was a friend or foe. 


\section{The Cambridge Professor's proposal for an honourable peace}

The movement for peace that emerged in the lead up to, and during, World War I took a definite turn toward a more thoughtful and humanist perspective compared to the primarily religious approach that had prevailed up to then. ${ }^{5}$ Perhaps most important in that regard, was the finance journalist Ralph Norman Angell and his influential book The Great Illusion (1911), which granted him the 1933 Nobel Peace Prize. Angell's main thesis was that, under the sophisticated stage of division of labour and financial integration then prevalent among European nations, an armed conflict and the consequent disruption of economic ties would imply a total cost many times greater than any anticipated reward from it (Angell 1911, chap. III). A few weeks after the war broke out, Goldsworthy Lowes Dickinson, King's College historian and philosopher, published his pamphlet "The War and the Way Out", in which he explained that governments have been ruled by the mistaken doctrine that they should expand themselves at the expense of the others. People, for their turn, are dragged into wars because they are uneducated and easily fooled by the press, possessing no control over their government's foreign policy (Dickinson 1914, pp. 7-26).

Together with other British intellectuals and politicians - such as Ramsay McDonald, Charles Trevelyan, Arthur Ponsonby, and Edmund D. Morel - Angell started a movement in London, on 5 September 1914, named the Union of Democratic Control (UDC). The organization's four mandated points, agreed at its first general council some days later held at Cambridge University, were: first, no transference of any province between governments without explicit assent from its people; second, no alliances with other nations without a democratic machinery in place to oversee the

\footnotetext{
${ }^{5}$ The pacifist circles in Britain were completely unprepared to face the massive scale of modern war. Those denominations like the Mennonites, the Quakers, the Jehovah Witnesses, and the Christadelphians, rejected violence based on the Holy Scriptures. Others had been affiliated to a few pacifist institutions, as the London Peace Society, created in 1816, which mainly congregated middle-class Evangelical reformers. The socialists, due to the large diversity of their doctrines, were unable to devise a unified strategy to avert war, with trade unions in all belligerent nations immediately rallying behind their governments (Ceadal 1980, pp. 1-30). The No Conscription Fellowship (NCF), created on 27 November 1914 by Archibald Fenner Brockway and Clifford Allen, became the most structured and persecuted pacifist organization in Britain during the war, providing moral and material support to conscientious objectors after 1916 (Brock and Young 1999, pp. 17-67; Rae 1970, pp. 90-93).
} 
government's foreign policy; third, Britain should no longer pursue the doctrine of the "Balance of Powers" on the continent but must, instead, support the creation of an international council; and, lastly, any peace settlement must also incorporate a prescribed general reduction in armaments (Cook 1972; Hanak 1963; Swanwick 1924, pp. 38-49).

Opposition to the then incipient pacifist movement primarily came from the British government, which, for the first time, introduced a pro-war propaganda campaign via the pen of dozens of accomplished writers. Their brief was to stir people's will to fight for liberty and civilization, while also denouncing all sorts of purported German barbaric acts. Additionally, after the enactment of the Defence of the Realm Act on 8 August 1914, the press came under a strict set of regulations, which specified the type of information that could be made known to the public and what must be avoided (Hochschild 2011, pp. 169-171, 222-225). ${ }^{6}$ The overall environment could not be more intimidating to any manifestation for a peaceful resolution of the ongoing conflict. As Catriona Pennell has observed about how public opinion in Britain saw the German menace:

At the outbreak of war, the majority of British people believed that Germany was their enemy and this feeling, in turn, compounded a 'mighty sense of righteous exaltation' about Britain and its cause. In many respects, the image of the enemy was the negative reverse side of the values identified with the nation (Pennell 2012, p. 91).

Pigou's personal involvement with the peace issue started off with a letter published by The Nation, on 6 February 1915, barely six months after Britain's declaration of war, and entitled "A Plea to the Statement of the Allied Terms". The piece's chief purpose was to set forth the best course of action for a quick ending to the conflict. From his experience with the Friends' Ambulance Unit, Pigou had driven close to the front and

\footnotetext{
${ }^{6}$ Although patriotism had been largely invoked by British radical politicians from the mid of the eighteenth century down to the Chartist movement to call for a more representative government, by the end of the nineteenth century the word began to designate loyalty to the institutions of the Kingdom, as well as the military defence of its interests overseas. When World War I broke out, patriotism had been already associated with jingoism by the British press, meaning by that term exacerbated nationalism and a war driven foreign policy (King 2014; Cunningham 1981).
} 
personally witnessed the first Battle of Ypres. ${ }^{7}$ His vivid and bold description of that event was instrumental in bringing home the cruelty reigning over the battlefield; and that account formed the narrative of his advocacy for a timely negotiated peace instead of a protracted battle to obtain Germany's unconditional surrender. As he specified in his letter:

$[T]$ he sorrow, terror, and pain that these things represent -the pitiful slaughter of the youth of seven nations, the awful waste of effort and of organizing power, the dulling and stunting of our human sympathies- all that is to be carried forward, not till our terms are granted, but till we, offering no terms whatever, have beaten our enemies to her knees! (Pigou 1915a, p. 590)

Pigou's frustration is evident from his expectation that the ongoing tragedy would continue until the 'enemies' have been beaten to their knees due to the stubbornness of the Allied leaders. Thinking rationally on the war campaign implied considering two alternative courses of action. Either there would be a long-drawn-out fight until a penal and crushing victory was reached, or else a fast and honourable peace for all parties involved. The first course was largely backed by the government's propaganda campaign, while many in the press required no less than the invasion of Germany, the surrender of its fleet, and a change in its constitutional system so that another attempt by its military elite at dominating Europe became impracticable. ${ }^{8}$ But what those who held to this hard-line position failed to comprehend, in Pigou's assessment, was that by bringing the German nation to its knees, such outcome amounted to having its whole thought and energy thenceforward concentrated on the preparation for a future full-scale retribution. "But Germany would not remain crushed forever, and in the period of her enforced submission the seeds of another, and perhaps more terrible conflict, will surely and steadily grow" (Pigou 1915a, p. 591).

\footnotetext{
${ }^{7}$ After the fall of Antwerp on 10 October 1914, the German army tried to reach the Channel ports in Belgium, but was detained by the Allies in a series of combats that became known collectively as the first Ypres Battle, which occurred between 19 October and 22 November 1914, resulting in over a 100 thousand casualties (Robbins 2002, pp. 33-34).

${ }^{8}$ For instance, on 15 September 1914, an editorial by The Times urged British forces to keep fighting until the bitter end: "We and our Allies owe it to those who will come after us to dispel forever the menace of Prussian militarism. [...] We shall only do it by carrying our victorious arms, at whatever cost, into the heart of the enemy's Empire" (The Times 1914, p. 9; our italics).
} 
The economic heart of Pigou's proposal, then, was based on an appraisal of the peace initiative along the lines of his earlier assessment of the advantages derived from industrial peace and on a full consideration of the unaccounted heavy losses caused by the war and ultimately borne by the common people. He is clearly asking readers to weigh up the commonly neglected costs of another 'terrible conflict' if the war is prolonged against the more predictable costs and benefits of setting terms and pursuing a negotiated settlement. The move for talks might look impertinent, concedes Pigou, but it still could have the capacity of putting an end to the senseless suffering of the warring nations. ${ }^{9}$ Otherwise, a true opportunity for peace may be allowed to go astray due exclusively to vanity disguised as a point of honour or yet, to the lack of unpassionate rational thinking. The German people, in addition, should not be condemned altogether without a sincere reflection on their motivation, which, for that matter, as explained in the letter, was quite different from their leaders'. This separation between the wicked instinct of the ruling classes and the good nature of the common man was critical to Pigou's argument, underpinning his intrepid claim for a spirit of condescendence by all nations in conflict.

And though many reject this view, yet they also agree that what now unites the German people -as distinct from the German Government- in whole-hearted support of the war is the firm belief that it is a war of self-defence. In view of this attitude of mind, and in view of the terrible record of her wounded and her dead, is there not ground for hope that, if honourable terms are offered frankly, Germany will accept them? (Pigou 1915a, p. 591).

The letter in question was not just the product of a momentary burst by Pigou. In an unpublished and undated manuscript entitled 'Terms of Peace' (Pigou 1915b), whose contents suggest its being written around the same time of his letter to The Nation, he provided more details about what the terms of a moderate peace would mean. First, there should be no collection of indemnities whatsoever, only the evacuation of the occupied regions, with reparations payments due exclusively to Belgium. Second, the German fleet must not be overtaken, and Germany should be allowed to keep most of her colonies. A compromise on the situation in Alsace-Lorraine should be reached, the same happening with Turkey. In a nutshell, Pigou's conception of how peace may be

\footnotetext{
${ }^{9}$ Pigou point here was not just hypothetical, for newspapers' reports stating Germany's willingness to talk peace had surfaced in the Danish press in late January and early February 1915, but just to be swiftly dismissed in Britain as void rumours (The Times 1915, p. 9).
} 
restored converged basically to an agreed return to the pre-war map of Europe, or how he designates it, the status quo ante bellum. The major resistance to this kind of proposal, he anticipates, would come forth not from the enemy, but from within Britain itself, where a "holy wrath" against Germany was being ceaselessly fuelled by the press, the Anglican Church and the official propaganda. People at home, he goes on arguing, do not really know what is taking place on the battlefield and, therefore, tend to think under the influence of a blind passion of nationalism. ${ }^{10}$

By publicly calling for terms of peace that were moderate in character and putting forward his case for this strategy at a time when the enemy was exacting a high price in terms of the thousands of British lives being lost, Pigou placed himself in the firing line of public outrage. The dilemma was clear, as expressed by a modern scholar on the politics of that period: "[H]ow do you oppose a war without seeming to undermine the husbands, fathers, and brothers of your fellow citizens whose lives are in danger?" (Hochschild 2011, p. 100).

\section{Reactions to Pigou's proposal and the Devonshire House lecture}

On 15 February 1915, the conservative daily newspaper The Morning Post ${ }^{11}$ published an editorial provocatively entitled "The Policy of Dane-Geld"12, ruthlessly attacking Pigou's peace proposal as absolutely misconceived, since Germany was still in control of Belgium, Northern France and Russian Poland and had not, moreover, shown any

\footnotetext{
${ }^{10}$ Alfred Marshall sent a letter to The Times, a few days after war broke out, on 22 August, to express his apprehension that despite the correctness of Britain's intervention on the conflict, the German citizen could become the unduly target of public scorn: "As a people, I believe them to be exceptionally conscientious and upright, sensitive to calls of duty, tender in their family affections, true and trusty in friendship. Therefore they are strong and to be feared, but not to be vilified" (Marshall 1914: 7). Marshall had visited Bavaria in the early 1880s and his economic thought was deeply influenced by Georg W.F. Hegel's historical philosophy (Groenewegen 1995, pp. 164-165, 190).

${ }^{11}$ The Morning Post circulated daily in London from 1772 to 1937, when it was merged into The Daily Telegraph. Its editor during the period from 1911 to 1937 was Howell Arthur Gwynne (1865-1950), an influential journalist who had covered much of the British Empire wars and followed a hard Tory line on foreign policy (The Times 1950, p. 8).

${ }^{12}$ The danegeld consisted in an historical tribute created by King Ethereld II (reign 978-1016) to buy off the Vikings so they would not invade England.
} 
sign of weakening her grip on those territories. Pigou, the editorial mocks, was trying to sell the bear skin before killing the beast. He was just one more of those few but eloquent apostles of pro-Germanism who preached surrender as magnanimity. Yet, the editorialist recalls, Pigou's sympathy towards Germany was not new, for during the tariff controversy a decade earlier, the Cambridge professor had dared to suggest that Britain allowed the use of some of her coal bases by German vessels to appease it after Canada decided for a preferential treatment to British goods. In brief, the aim of the whole editorial was, on the one hand, to reject Pigou's proposal as coming from a friend of the enemy and, on the other, to endorse the very course of action the Professor was opposing: the war must to be fought to the very end.

Since we are launched upon this war, the only way to end it is victory. As to concessions, they might alienate our friends, but they certainly would not conciliate the enemy. ... But we seem to remember that Professor Pigou has always been amiably inclined to Germany. His policy may be formulated thus: If the Germans want anything, by all means let them have it (The Morning Post 1915a, p. 6).

The editorial sparked a fierce reaction through letters and editorials in several newspapers around Britain naming Pigou a traitor, poltroon, and other equally disparaging epithets. The Chronicle, for instance, from 13 February 1915, claimed that any meaningful peace must contemplate the full eradication of Germany's militarist culture. Pigou, for that matter, was just a friend of the enemy trying to strike down the punitive arm of the British Tommy (The Chronicle 1915, p. 8). The Sheffield Independent, on the same date, remarked that if Pigou's advice had been followed during the Boer War (1899-1902), the troops coming from South Africa to join the British army would now be fighting for Germany (The Sheffield 1915, p. 4). The Devon and Exeter Gazette, in its 19 February 1915 issue, ironically called Pigou a "brilliant pedagogue" who wanted Germany not to be held accountable for the crime of devastating Europe (The Devon 1915, p. 3). On 26 February, a former student of Pigou had a letter published in The Morning Post accusing the Professor of being unpatriotic and leading a socialistic clique at Cambridge (Smith 1915).

However, Pigou did receive a few words of support in a letter to The Nation signed by Bertrand Russell on 13 February 1915. Anyone seeking wisdom and justice, instead of blind revenge, assured the philosopher, would find it in Pigou's proposal. If peace could be achieved with honour and without humiliation, Russell believed that 
such achievement would be enough to appease German minds and rob the Prussian militarists of their basis of support, eliminating, therefore, the chief motive for further sacrifices. The Allies' reluctance to make public their terms to end the war, as recommended by Pigou, ponders Russell, could only originate in two factors: the fear that their power was insufficient to obtain what is just, or else, the conviction that they had the opportunity of obtaining more than could be expected from a just outcome (Russell 1915). ${ }^{13}$

The overall atmosphere across the nation and specially at Cambridge University, though, was widely hostile to any conciliatory rhetoric. Thus, Archdeacon William Cunningham and William Wyse, former lecturer at Trinity, wrote in the same issue of The Nation condemning Pigou's proposal as utterly naïve for its assuming without any evidence Germany's disposition to seat down at the negotiation table (Cunningham 1915; Wyse 1915). On 11 March 1915, the professor of Zoology and Master of Christ's, Arthur E. Shipley, wrote to The Morning Post complaining about the excessive attention being dedicated to Pigou, who was supposedly only searching for the limelight and whose opinions did not represent the patriotic spirit prevailing at the University, which had sent more of his young members to the front than any other institution in the whole Empire. "Out of our fifty professors, I doubt you could find a single one who holds the same position as Professor Pigou: Certainly, the overwhelming majority hold very different views" (The Cambridge Independent Press 1915b, p. 6). ${ }^{14}$

Pigou's answer to the personal attacks appeared in The Morning Post, on 23 February 1915. After a summary of his ideas on the peace issue, he derides the criticisms of his proposal for their being devoid of reason and conceived only to rouse

\footnotetext{
${ }^{13}$ On Russell's pacifist writings and activities, his involvement with the NCF, the dismissal from Trinity in 1916 and his imprisonment in 1918, see Wallace (1988, pp. 125-160).

${ }^{14}$ From 3,699 male undergraduates in residence at Cambridge in 1910, that number fell to only 575 in the Easter Term of 1916. Many of the younger fellows joined the forces, while several of the more aged professors took up some form of war related work. Open spaces at King's and Trinity were converted into a military hospital; the Army's $6^{\text {th }}$ Division from Ireland stationed in Cambridge for some time and, afterwards, Caius became the headquarters of the $1^{\text {st }}$ Division. Despite the appeal for peace from some notable figures, patriotism and loyalty to the King run high at the University during the war and even after the Armistice (Brooke 1993, pp. 331-340).
} 
passions instead of persuading minds. He argues also that his critics and detractors, including the newspaper's editor, were simply trying to infuse the readers of the popular press with prejudice and passion as a travesty of nationalism, showing also utter disregard for the general affliction ravaging the warring nations.

The youth of seven nations are marching without complaint to death, disease, and wounds; fugitives are streaming from homes laid desolate; Europe is a continent in mourning. Will the heroes of the smoking-room merely storm when one who has seen a little of these things pleads that by policy this tragedy might perhaps be stayed? I do not ask now for assent to the thesis that I put forward in the Nation; but I do ask for it a candid and unprejudiced consideration, in which reason and not passion shall be the judge (Pigou 1915c, p. 6).

Shortly after that, Pigou seized another opportunity to plead his case for peace, this time around at the Cambridge Union Society, over which he himself had presided during his undergraduate days. In front of a packed audience, on 13 March 1915, Pigou moved that the house would welcome an early offer of moderate terms of peace by the Allies. He basically followed the arguments sketched in his the "Terms of Peace" (1915b), reiterating that by "moderate" peace he meant the evacuation of occupied zones by Germany with no punishments imposed by the Allies on either the Kaiser or the German people. The continuance of the war for reaping compensations would only bring about more loss of lives and devastation for friends and foes of Britain (The Cambridge Independent Press 1915a, p. 7; The Cambridge Magazine 1915, p. 336).

Notwithstanding the support offered by the next speaker, Hubert D. Henderson from Emmanuel, Pigou's rather idealistic motion would not fail to elicit severe opposition. The Professor of Moral Philosophy at King's, William R. Sorley, accused Pigou of having absolutely no clue about the implications of what he was advocating. Until that date, there had been no fight or destruction on German soil, and any peace offer would be simply thrown back at the Allies' face, since the enemy's motto was that what had been conquered by the sword shall be kept by the sword. What the moment required instead was the prosecution of the war with all energies, and not the insistence on the offer of any sort of inopportune peace terms. Pigou, regretted Sorley, entertained an extremely implausible reading of the German mindset, wishing to stake the whole future of Britain on a crude kind of social psychology (The Cambridge Independent Press 1915a: 7). 
Later that year, under the auspices of the London Peace Committee, run by the Society of Friends, Pigou delivered a speech entitled "New Peace for Old" to a crowd of about a hundred people on the evening of 25 November at the Devonshire House on Bishopsgate. ${ }^{15}$ The building have been historically the central headquarters and meeting place for Quakers in London since the 1661 Great Fire until their definitive move to the Friends House on Euston Road in 1927. Pigou commenced his address by contesting the common assumption that England was at war with the German people. That belief, he explains, had been encouraged by the press on both sides, but particularly by British newspapers, which inflamed unreasonable passions against sixty-million people who were no bloody criminals, but rather kindred in race and temper, and living under the belief they have been waging a war of self-defence. The full weight of a total defeat of German militarism, as urged by numerous voices in Britain, would fall upon the shoulders of the humblest people in Germany, who have been already penalized by the loss of their sons while enduring a harsh state of material scarcity and rampant inflation. These kinds of miseries, Pigou assured his listeners, were cruel enough to the ordinary German man, there being no need to strive for making him suffer even further by additional death and deprivation. Besides that, a crushing victory by the Allies would only make people in Germany believe they had been punished for crimes they did not commit, nurturing thus further militarism within the nation. In short, total victory, although the ideal outcome for Britain, would be far from constituting the best resolution of the conflict in the long haul due the overwhelming feeling of resentment it would rise among the German people. Such advice, as seen, came straight from the analysis developed in Industrial Peace.

But military defeat would no more persuade them to stop that kind of militarism than it would stop us from building another big Navy if ours were overthrown. Germans would

\footnotetext{
15 The speech is reported in its main topics by The Morning Post and reproduced by The Cambridge Independent Press of 3 December 1915. The second part of Pigou's talk was published in unabridged form under the title "The Conditions of a Permanent Peace" in Norman Angell's weekly magazine War and Peace, in its January 1916 issue (Pigou 1916). Pigou had been in contact with the Quakers through his student Philip Noel-Baker, one of the founders of the Friends Ambulance Unit and later professor at the London School of Economics, Labour politician and active pacifist who would receive the Nobel Peace Prize in 1959 (Kumekawa 2017, chap. 4).
} 
argue that they had been defeated by militarist Russia, militarist France and marinest England (The Cambridge Independent Press 1915c, p. 2).

Any peace worthy of the name must, in Pigou's assessment, establish conditions that do not carry in themselves the seeds of another war. From this standpoint, he identifies four necessary corollaries of a lasting peace. First, regard should be had for all concerned parties in any peace agreement. Or still, people should not be forced into membership of a state they do not wish to belong. All occupied territories must be evacuated, and the respective populations be allowed to decide their own fate. Second, the terms of peace should not leave the people of any nation with a feeling of outrage or of humiliation, as it would certainly happen if compensation was demanded from Germany besides the sums due from the damage done to Belgium. Third, a settlement should not include a strategic guarantee involving one nation seizing the military assets of another, as by the capture of the German fleet of an eventual taking of Belgium ports by Germany, so that peace would not be built upon mutual fear. Lastly, the need for nations to display true goodwill towards each other should be reinforced, starting from the dealings in relation to the terms of peace and then expanding over time through economic engagement.

On this last aspect, Pigou develops his previous position by underlining the importance of mutually beneficial economic treaties, in the spirit of free trade, capable of preserving European peace once a cessation of the conflict had been secured. That would buy the necessary time for the deep wartime wounds to heal, paving the way for the creation down the road of an international system of arbitration to defuse future conflicts. From that point on could evolve, finally, a supranational organization in the form of an international league for peace, as recommended by the intellectuals affiliated with the UDC. In short, Pigou made clear to his audience that the end of the war must be quickly followed by an open economic commitment to free trade by all contending parties so that political stability could follow in a such a manner to preserve international concord.

The new peace ought to be ushered in, not by boycotts and tariff reprisals, but by systems of commercial treaties made in the joint and common interests of the nations that have been at war. ... Gradually, this network of agreement will spread till at last something in the nature of a general league of peace emerges. When it has emerged there will be no need for special treaties limiting expenditure in armaments, for the need for armaments being lessened the expenditure upon them will automatically decline (Pigou 1916, p. 55). 
Pigou's recommendation on this aspect anticipated the one to be adopted in 1919 by John Maynard Keynes in The Economic Consequences of the Peace, where it was deeply regretted that top priority at the Peace Treaty had been given to short-sighted political machinations, instead of to the pressing financial and economic needs of the continent (Keynes [1919] 1920, chap. VI). ${ }^{16}$ Anyway, the Devonshire House lecture did not pass unnoticed by the press. The very next day, The Morning Post, once again, published a ruthless editorial entitled "Professorial Pedantry". It labelled the speech a "mischievous exercise", having as its unique purpose the dissemination of doubt in the mind of the British people by condoning Germany's outrageous aggression. Pigou's plan was again characterised as "bribing the enemy" to undo its wrongs; and such course of action, insisted the editor, was repugnant to British conscience and dignity. Pigou's only concern was to spare Germany the fate she bestowed on other nations, a proposition indignant to any right-feeling citizen. But the true Achilles heel of Pigou's entire notion of moderate peace, according to the editorial, consisted in the very notion of status quo ante bellum, that is, a fantasised return to the pre-war situation which lacked any realistic feasibility.

Professor Pigou does not seem to realize yet that the idea of bribing Germany into the undoing of the wrongs that she has committed is as repugnant to the British conscience as to the British dignity. ... This learned Professor omits to take account of one factor - that goodwill is impossible without respect, and that peace is impossible without the frustration of wrong-doing. His status quo ante bellum is, in fact, impossible: for that status quo has already been destroyed beyond the possibility of restoration (The Morning Post 1915b, p. $6)$.

At this juncture, Pigou's activities as an activist intellectual publicly advocating for a negotiated end to the war almost came to a stop. Not that the Professor had changed his mind, for he had not. Indeed, in 1917 he signed a petition for peace, along with other 200 thousand people and presented to David Lloyd George by the Peace Negotiation Committee (The Yorkshire Post 1917, p. 6). But once general conscription was introduced in early 1916, Pigou realised that his efforts had failed to have any influence either on the British Government, or on public opinion more generally, over the issue of

\footnotetext{
${ }^{16}$ Keynes's criticism of David Lloyd George's actions in Versailles blocked his nomination for the British Academy in 1919, the same fate of Pigou the year before because of his pacifism. Both ended up elected to the Academy only in 1927 (Pigou) and 1929 (Keynes) (Winch 2015).
} 
war diplomacy. This late war period also marks the opening of a new and distressing chapter in his life related to his contentious exemption from military service by request from Cambridge University (Kumekawa 2017, pp. 83-110; Aslanbeigui 1992; Deane 2001, pp. 256-261).

\section{Pigou's post-war reflections on peace and war}

After the conflict, in 1920, Pigou published The Economics of Welfare as a revised edition of Wealth and Welfare, but now incorporating many of his previous work over the war years. Two extensive new parts were added (III and IV), dealing respectively with labour disputes (18 chapters) and government finance (11 chapters), comprising in total over three hundred pages. Almost absent from Wealth and Welfare, the subject of industrial peace was now rekindled by Pigou on the analytical basis that strikes have a negative impact on the national dividend and, therefore, on economic welfare as well. Pigou remains though somewhat sceptical about the power of laws or institutional arrangements to fully prevent a recurrence of industrial clashes when trust and goodwill were absent. And that would be the case not only of industrial activity, but also of international relations, as he swiftly points out when commenting on the disruptive effect of strikes not only on economic activity but also on the working people through their loss of working skills, over indebtedness and children malnourishment.

\footnotetext{
Hence the eagerness of social reformers to build up and fortify the machinery of industrial peace. They recognise, indeed, that in the work of pacification constitutions and agreements cannot accomplish much. In industrial, as in international negotiations, perfection of machinery counts for far less than good faith and good will. Care must therefore, be taken not to stress unduly matters of mere technique (Pigou 1920, p. 366).
}

Aware of how public opinion could be swayed by the inflamed rhetoric of partisanship and conflict, Pigou stresses once more the importance of having representatives of the opposing parties engaged with sincere bona fide in negotiations over industrial and labour issues. Negotiated outcomes are preferred to decisions reached by direct referendum among the working people because the latter can be easily manipulated towards bellicosity, a situation that would preclude the indispensable rational approach to conciliation (Pigou 1920, pp. 391-400). For the purpose of this paper, the substantial point is that Pigou again extends his case for negotiations, developed in the context of industrial peace, to the sphere of international diplomacy. Whatever action increasing 
the costs of war, observes Pigou, such as alliances among powerful nations, could turn a diplomatic stalemate into a peaceful settlement, for an increased strength on one side tends to be accompanied by a countervailing movement on the other.

This tendency is exhibited in international, as well as in industrial, negotiations. If the adjustment of some political difference by war means adjustment by a world war embracing powerful alliances on both sides, the enormous probable cost of a fight makes it certain that, unless the stake at issue is of almost inconceivable importance, some range of practicable bargains will be available (Pigou 1920, p. 466).

Pigou's most articulate analysis of war politics, however, was to come forth in The Political Economy of War (1921). Right at the introduction, he admits that the maintenance of peace among European nations in the future required higher than normal spending on military defence, comprising the army, the navy and especially the air force. Under the permanent shadow of an international engagement, says the Professor, state intervention in the economy should be carried out besides those cases conceived to improve welfare -as progressive taxation and public works. This threat had three immediate implications. First, there should be a reduction in the nation's reliance on foreign supplies of food through a system of national granaries. Second, the state should actively sustain a merchant fleet large enough to accommodate a sudden surge in imports. And finally, some protection must be afforded to strategic industries with high technological content which had been proven essential to armaments production, such as magneto and optical glasses making, among others. Those preventive measures of defensive nature, though, did not represent a meaningful departure by Pigou from his more general stance in favour of free trade, as he would insist upon years later, even after the return of protectionist policies to Britain (Pigou 1921, pp. 4-11). ${ }^{17}$

When discussing the forces pushing for an international conflict during peacetime, Pigou drew attention to the interplay between psychological and economic aspects of social and political activities. In that regard, the desire for domination prevalent among the people of great European nations like Britain, France and

\footnotetext{
${ }^{17}$ Speaking at the University of London, in 1950, Pigou once more insisted on the beneficial role of foreign trade: "If we were isolated from the rest of the world, we couldn't get these things [imports] and would have to make do instead with other things we don't want so much. The real income we should get wouldn’t yield so much satisfaction" (Pigou 1952: 70).
} 
Germany, could be found in many instances of daily life, such as when a boy bullies another in school; or when a white man demands subordination from colonized people in the tropics. On the level of international relations, this same proclivity makes men in power unwilling to relinquish the nation's yoke over its colonial territories, since any step in that direction would be interpreted as a sign of humiliation and dishonor. At the same time, influential interests are formed within society that are highly reliant on the deepening of the existing colonial structure. This is the case of importers of raw materials, of financiers tied up with loans to controlled regions, of concession seekers, and of domestic producers of munitions and weapons. Even though they together represent just a small fraction of society, they are commonly well organized and always ready to enter into obscure arrangements with politicians to keep their reaping up the hefty profits from these shadowy activities.

As long as European governments remained captive to these kinds of special interests, with authorities supporting traders, financiers and war munitions producers through tariff wars and the forceful search for new spheres of influence, this vicious spiral was bound to escalate, bringing war progressively closer. Within that context, Pigou points out also that producers of armaments have worked tirelessly, through their influence upon the press and politics, to intensify suspicion and rivalry among governments. As the fear of war feeds into itself, and the build-up of armaments invites conquest and animosity, each nation sees a new subjugated territory as the source of fresh soldiers to its army and the location of a new military basis against its rivals. Despite the fact that wars for loot or territorial conquest always result in huge losses to the parties involved far beyond any projected gain, the prevalence of private interests over the common good makes the likelihood of a conflict greater by the day as preparations to avoid it grow (Pigou 1921, pp. 16-24).

A way out of this dreadful tangle of interests leading to bellicose consequences was at the reach of governments, however, if they decided to withdraw their backing of traders and speculators dealing in colonial territories. Such recommendation, we must notice, represented indeed a remarkable advance by Pigou as regards his early endorsement of British colonial policy. Beyond that, he advises that the great powers must actively prevent the people of underdeveloped areas from being exploited by European unscrupulous adventurers, this prophylactic measure constituting another 
essential step to preserve international harmony. Finally, international cooperation, free trade and the lifting of commercial restrictions on colonial possessions would mean a huge step towards peace by weaving together the fate of different peoples, a prospect that would hardly fail to abate the fear of war while nurturing mutual goodwill across national boundaries (Pigou 1921, pp. 24-29).

\section{Concluding remarks}

Pigou's intervention in public debate over what Britain should do towards Germany to open a window to peace was in large measure a reflection of his previous theoretical contributions on international trade, industrial peace and welfare. Initially, he endeavoured to raise the public awareness that the war had indeed massive human and material costs, a fact hardly acknowledged by authorities and the press, and which would far surpass any expected compensation from the enemy. In brief, to Pigou, war mongers had an utter disregard for the quickly deteriorating welfare of the common people on both sides of the trenches.

Still, the lessons from his work in industrial disputes indicated that any lasting move towards peace should include all parties affected by the settlement, meaning that the peoples in invaded areas must be consulted about their fate, be that the annexation to some country or even full sovereignty. Also, in that regard, the strategy of an all-out victory against Germany, with the seizure of its fleet, a military invasion and the payment of reparations, would inflict disproportionate penalty on one side of the conflict. Although such outcome might serve well Allied interests, the best scenario for one party was often unsustainable when the other party felt overpowered and willing to exact revenge sometime in future, as would happen with the German people in case of total defeat. Any lasting peace, as envisioned by Pigou, required a mutual agreed settlement, as that would encourage the development of genuine goodwill, economic integration through free trade, and the dismantling of private interests feeding into the colonial system.

One can, of course, argue that Pigou's approach to peace displayed an unwarranted optimism about Germany's disposition to negotiate. And the appropriateness of Pigou's support for a return to the pre-war order, which was no doubt introduced to confine issues to be addressed to a manageable range, can also be questioned as unrealistic. In fact, Pigou himself even stepped away from that position 
in his post war assessment of the dangers of excessive reliance on colonial arrangements. Yet the fundamental and original aspect of Pigou's analysis lies in the recognition that the economic and social consequences of the war were simply far more adverse and harsher than any of the corresponding consequences of a peace secured through negotiation. The main contribution of this paper, therefore, is the demonstration that Pigou reached such conclusion based upon a theoretical frame of analysis he had already developed during his pre-war investigations of protection, industrial peace and welfare, and which he sought to improve upon in the immediate post-war years.

\section{References}

Newspapers' reports and editorials

The Cambridge Independent Press.1915a. "The Terms of Peace. Professor Pigou Urges Moderate Policy. Spirited Debate at Union.” 12 March: 2.

The Cambridge Independent Press. 1915b. "Professor Pigou's Views Not Representative of Cambridge University”. 19 March: 6.

The Cambridge Independent Press. 1915c. "Professor A.C. Pigou Thinks German

People Have Been Punished Enough. Amazing Peace Proposal.” 3 December: 2.

The Cambridge Magazine. 1915. "Professor Pigou and Peace.” 13 March: 336.

The Chronicle. 1915. "Editorial." 13 February: 8.

The Devon and Exeter Gazette. 1915. "Our London Letter.” 19 February: 3.

The Morning Post. 1915a. "The policy of Dane-Geld.” 15 February: 6.

The Morning Post. 1915b. "Professorial Pedantry." 26 November: 6.

The Sheffield Daily Independent. 1915. "When Peace Terms Are Stated." 13 February: 4.

The Times. 1914. "The Pursuit of the Germans." 15 September, Issue 40636: 9.

The Times. 1915. "More Peace Talk.” 1 February, Issue 40766: 9.

The Times. 1950. “Mr. H. A. Gwynne.” 27 June, Issue 51728: 8. 
The Yorkshire Post. 1917. "A Peace Memorial to the Government." August 18: 6 $\underline{\text { Other references }}$

Arthmar, R. and McLure, M. 2017a. "Cambridge Theories of Welfare Economics", in R. Cord (ed.), The Palgrave Companion to Cambridge Economics. London: Palgrave Macmillan, pp. 51-71.

Arthmar, R. and McLure, M. 2017b. "Pigou on War Finance and Welfare." History of Economics Review 66(1): 2-18.

Aslanbeigui, N. 1992. "Foxwell's Aims and Pigou's Military Service: A Malicious Episode?" Journal of the History of Economic Thought 14(1): 96-109.

Aslanbeigui, N. and Oakes, G. 2015. Arthur Cecil Pigou. Houndmills: Palgrave Macmillan.

Aslanbeigui, N. and Oakes, G. 2016. "The Great War and the Genesis of Pigou's $A$ Study of Public Finance." Economia 6(4): 487-513.

Angell, N. 1913. The Great Illusion. A Study of the Relation of Military Power to National Advantage. London: G.P. Putnam's Son.

Brock, P. and Young, N. 1999. Pacifism in the Twentieth Century. Syracuse: Syracuse University Press.

Brooke, C.N.L. 1993. A History of the University of Cambridge. Volume IV 1870-1990. Cambridge: Cambridge University Press.

Ceadal, M. 1980. Pacifism in Britain 1914-1945: The Defining of a Faith. Oxford: Clarendon Press.

Coats, A. W. 1968. "Political Economy and the Tariff Reform Campaign of 1903." Journal of Law and Economics, 11(1): 181-229.

Cook, B. W. 1972. "Democracy in Wartime: Antimilitarism in England and the United States, 1914-1918." American Studies, 13(1): 51-68.

Cunningham, W. 1915. "The Policy of the Allies.” The Nation, 13 February: 619.

Cunningham, H. 1981. “The Language of Patriotism, 1750-1914.” History Workshop, 12(1): 8-33.

Deane, P. 2001. The Life and Times of John Neville Keynes. A Beacon in the Tempest. Cheltenham: Edward Elgar. 
Dickinson, G.L. 1914. The War and the Way Out. London: Chancery Lane Press.

Groenewegen, P. 2007. Alfred Marshall: Economist 1842-1924. London: Palgrave Macmillan.

Hanak, H. 1963. "The Union of Democratic Control during the First World War." Bulletin of the Institute of Historical Research, 36(94): 168-180.

Hochschild, A. 2011. To End All Wars. How the First World War Divided Britain. London: Pan Macmillan.

Keynes, J. M. [1919] 1920. The Economic Consequences of the Peace. New York: Harcourt, Brace and Howe.

King, E. 2014. “The Emergence of 'Jingo' and 'Jingoism' as Political Term in Public Debate in Great Britain (1878-1880)". Journal of Historical Pragmatics 15(2): 292-313.

Knight, K.L. 2018. A.C. Pigou and "Marshallian” Thought Style. London: Palgrave Macmillan.

Kumekawa, I. 2017. The First Serious Optimist: A.C. Pigou and the Birth of Welfare Economics. Princeton: Princeton University Press.

Marshall, A. 1914. "A fight to a finish". Letter to The Times, Issue 40612, August 22, 7.

McLure, M. 2012. “A.C. Pigou's Wealth and Welfare.” History of Economics Review, 56(1): 101-116.

Pennell, C. 2012. A Kingdom United. Popular Responses to the Outbreak of the First World War in Britain and Ireland. Oxford: Oxford University Press.

Pigou, A.C. 1904. The Riddle of the Tariff. London: R. Brimley Johnson.

Pigou, A.C. 1905. Principles and Methods of Industrial Peace. London: Macmillan.

Pigou, A.C. 1912. Wealth and Welfare. London: Macmillan.

Pigou, A.C. 1915a. "A Plea to the Statement of the Allied Terms." The Nation, 6 February: 590-591.

Pigou, A.C. 1915b. Terms of Peace. Cambridge: Marshall Library of Economics, A. C. Pigou Papers. 
Pigou, A.C. 1915c. "The Policy of Dane-Geld. A Reply from Professor Pigou." The Morning Post, 23 February: 6.

Pigou, A.C. 1916. “The Conditions of a Permanent Peace.” War and Peace, 3(28): 5455.

Pigou, A.C. 1920. The Economics of Welfare. London: Macmillan.

Pigou, A.C. 1921. Political Economy of War. London: Macmillan.

Pigou, A.C. 1935. Economics in Practice. Six Lectures on Current Issues. London: Macmillan.

Pigou, A.C. 1952. Essays in Economics. London: Macmillan.

Pigou, A.C. 1965. Essays in Applied Economics. London: Frank Cass.

Rae, J. 1970. Conscience \& Politics. The British Government and the Conscientious Objector to Military Service 1916-1919. London: Oxford University Press.

Robbins, K. 2002. The First World War. Oxford: Oxford University Press.

Russell, B. 1915. "Letter to the Editor". The Nation, February 13: 619.

Shields, R.A. 1965. "Imperial Reaction to the Fielding Tariff of 1897." The Canadian Journal of Economics and Political Science, 31(4): 524-537.

Smith, S.H. 1915. "The Policy of Dane-Geld.” The Morning Post, 26 February: 6.

Swanwick, H.L. M. 1924. Builders of Peace Being a Ten Years' History of the Union of Democratic Control. London: Swarthmore.

Wallace, S. 1988. War and the Image of Germany. British Academics 1914-1918. Edinburgh: John Donald.

Winch, D. 2015. "Keynes and the British Academy". The Historical Journal, 57(3): $751-771$.

Wyse, W. 1915. "Letter to the Editor.” The Nation, 13 February: 619 